Cellular Physiology
and Biochemistry and Biochemistry Publissed online: 1March 07,2017

Accepted: February 16, 2017

This article is licensed under the Creative Commons Attribution-NonCommercial-NoDerivatives 4.0 International License (CC BY-NC-ND) (http://www.karger.com/Services/OpenAccessLicense). Usage and distribution for commercial purposes as well as any distribution of modified material requires written permission.

Letter to the Editor

\title{
HyperCKemia instead of Hyperkalemia in Chorea-Acanthocytosis
}

\author{
Adrian Danek ${ }^{\mathrm{a}} \quad$ Ruth H. Walker \\ aNeurologische Klinik, Ludwig-Maximilians-Universität, München, Germany; ${ }^{b}$ Department of Neurology, \\ James J. Peters Veterans Affairs Medical Center, Bronx, NY, USA
}

\section{Key Words}

Chorea-acanthocytosis • HyperCKemia • Rhabdomysarcoma cell line

To the Editors,

The group of Florian Lang is to be congratulated for their continued productive efforts to elucidate pathomechanisms of the neurodegenerative disease chorea-acanthocytosis (ChAc). Lang and collaborators have employed a variety of cell models to identify the functions of the ChAc protein, chorein, and most recently further specified its role for rhabdomyosarcoma cell survival in this journal [1].

With all respect, however, we must point out a continuing error in their series of publications. When the condition of ChAc is introduced, it is regularly described by these authors as being characterized by "chronic hyperkalemia" [1-7]. This notion can lead to erroneous assumptions in the clinic, in discussions of pathophysiology, and in experimental design or interpretation. Hyperkalemia has never been noted to be a clinical feature of ChAc over many years of clinical observations [8-9]. A dictation, spelling, or proofing error must have caused the mistake, and clearly "hyperCKemia" was originally intended. Elevated serum levels of creatine kinase (CK) are a well-recognized common finding in ChAc and have long been discussed as indicative of skeletal muscle cell membrane dysfunction. This observation might be of relevance for the ZF alveolar rhabdomyosarcoma cells that were studied by $\mathrm{Yu}$ et al. as they derive from skeletal muscle.

We also noted incidentally that reference 4 in their current bibliography appears irrelevant to the current work. We strongly suspect that the authors intended to refer to another work in which ChAc was discussed with respect to possible heart muscle involvement [10]. The erroneous reference to a study of sudden death in childhood cardiomyopathy by the same authors Mohiddin and Fananapazir [11] can be traced through previous publications [2,7]. We conclude that an initial mistake of author attribution became reiterated in the course of manuscript production.

For future publications, we would like to encourage Lang and colleagues to minimize confusion by ensuring that their errors are not propagated further.

Prof. Dr. med. Adrian Danek and Ruth H. Walker, M.B., Ch.B., Ph.D.,

\section{KARGER}

\footnotetext{
Neurologische Klinik, Ludwig-Maximilians-Universität

Postfach 701260, D-81366 München, (Germany) and Department of Neurology (127),

James J. Peters Veterans Affairs Medical Center, Bronx, NY 10468

E-Mail danek@Imu.de / ruth.walker@mssm.edu
} 


\section{Cellular Physiology Cell Physiol Biochem 2017;41:1267-1268 \begin{tabular}{ll|l} 
DOI: 10.1159/000464390 & and Biochemistry Publisned online: 1varch 07, 2017 & $\begin{array}{l}\text { O 2017 The Author(s). Published by S. Karger AG, Basel } \\
\text { www.karger.com/cpb }\end{array}$
\end{tabular} \\ Danek/Walker: HyperCKemia (not hyperkalemia) in ChAc}

\section{References}

1 Yu W, Honisch S, Schmidt S, Yan J, Schmid E, Alkahtani S, Alarifi S, Stournaras C, Lang F: Chorein sensitive Orai1 expression and store operated Ca2+ entry in rhabdomyosarcoma cells. Cell Physiol Biochem 2016;40:1141-1152.

2 Föller M, Hermann A, Gu S, Alesutan I, Qadri SM, Borst O, Schmidt EM, Schiele F, vom Hagen JM, Saft C, Schöls L, Lerche H, Stournaras C, Storch A, Lang F: Chorein-sensitive polymerization of cortical actin and suicidal cell death in chorea-acanthocytosis. FASEB J 2012;26:1526-1534.

-3 Alesutan I, Seifert J, Pakladok T, Rheinlaender J, Lebedeva A, Towhid ST, , Stournaras C, Voelkl J, Schäffer TE, Lang F: Chorein sensitivity of actin polymerization, cell shape and mechanical stiffness of vascular endothelial cells. Cell Physiol Biochem 2013;32:728-742.

4 Schmidt E, Schmid E, Münzer P, Hermann A, Gu S, Schaller M, Borst O, Föller M, Gawaz M, Schöls L, Storch A, Stournaras C, Lang F: Chorein - connection between a neurodegenerative disease and platelet function. Brain Behav Immun 2013;32,Supplement:e24.

5 Schmidt E-M, Schmid E, Münzer P, Hermann A, Eyrich A-K, Russo A, Walker B, Gu S, vom Hagen JM, Faggio C, Schaller M, Föller M, Schöls L, Gawaz M, Borst O, Storch A, Stournaras C, Lang F: Chorein sensitivity of cytoskeletal organization and degranulation of platelets. FASEB J 2013;27:2799-2806.

6 Honisch S, Fehrenbacher B, Lebedeva A, Alesutan I, Castor T, Alkahtani S, Alarifi S, Schaller M, Stournaras C, Lang F: Chorein sensitive dopamine release from pheochromocytoma (PC12) cells. Neurosignals 2015;23:1-10.

7 Honisch S, Yu W, Liu G, Alesutan I, Towhid ST, Tsapara A, Schleicher S, Handgretinger R, Stournaras C, Lang F: Chorein addiction in VPS13A overexpressing rhabdomyosarcoma cells. Oncotarget 2015;6:10309_ 10319.

8 Velayos Baeza A, Dobson-Stone C, Rampoldi L, Bader B, Walker RH, Danek A, Monaco AP: ChoreaAcanthocytosis; in Pagon RA, Adam MP, Ardinger HH, et al (eds): GeneReviews@. Seattle (WA), University of Washington, Seattle, 2014. Available from: http://www.ncbi.nlm.nih.gov/books/NBK1387/

-9 Pappas SS, Bonifacino J, Danek A, Dauer WT, De M, De Franceschi L, DiPaolo G, Fuller R, Haucke V, Hermann A, Kornmann B, Landwehrmeyer B, Levin J, Neiman AM, Rudnicki DD, Sibon O, Velayos-Baeza A, Vonk JJ, Walker RH, Weisman LS, Albin RL: Eighth International Chorea-Acanthocytosis Symposium: Summary of workshop discussion and action points. Tremor Other Hyperkinet Mov (NY) 2017;7:doi: 10.7916/ D8XD127W.

10 Mohiddin SA, Fananapazir L: Cardiac involvement in the neuroacanthocytosis syndromes; in Danek A (ed): Neuroacanthocytosis Syndromes. Springer Netherlands, 2004, pp 139-152.

11 Mohiddin SA, Fananapazir L: Systolic compression of epicardial coronary and intramural arteries in children with hypertrophic cardiomyopathy. Tex Heart Inst J 2002;29:290-298. 